\title{
W(h)ither the academy? An exploration of the role of university social work in shaping the future of social work in Europe
}

\author{
Martin Webber, Mark Hardy, Simon Cauvain, Aino Kääriäinen, Mirja Satka, \\ Laura Yliruka \& Ian Shaw
}

To cite this article: Martin Webber, Mark Hardy, Simon Cauvain, Aino Kääriäinen, Mirja Satka, Laura Yliruka \& Ian Shaw (2014) W(h)ither the academy? An exploration of the role of university social work in shaping the future of social work in Europe, European Journal of Social Work, 17:5, 627-640, DOI: 10.1080/13691457.2014.912202

To link to this article: http://dx.doi.org/10.1080/13691457.2014.912202

Published online: 07 May 2014.

Submit your article to this journal $\pi$

Џll Article views: 313

Q View related articles $\longleftarrow$

View Crossmark data $\nearrow$

Citing articles: 1 View citing articles ¿ð 


\title{
W(h)ither the academy? An exploration of the role of university social work in shaping the future of social work in Europe
}

\section{Kuihtuuko akateeminen? Tutkimus yliopistollisesta sosiaalityöstä eurooppalaisen sosiaalityön tulevaisuuden tekijänä}

\author{
Martin Webber ${ }^{\mathrm{a} *}$, Mark Hardy ${ }^{\mathrm{a}}$, Simon Cauvain ${ }^{\mathrm{a}}$, Aino Kääriäinen ${ }^{\mathrm{b}, \mathrm{c}}$, Mirja Satka ${ }^{\mathrm{b}, \mathrm{c}}$, \\ Laura Yliruka ${ }^{\mathrm{b}, \mathrm{c}}$ and Ian Shaw ${ }^{\mathrm{a}, \mathrm{d}}$ \\ ${ }^{a}$ Department of Social Policy and Social Work, University of York, York, UK; ${ }^{b}$ Department of Social \\ Research, University of Helsinki, Helsinki, Finland; ${ }^{c}$ Heikki Waris Institute, Helsinki, Finland; \\ ${ }^{d}$ Department of Sociology and Social Work, Aalborg University, Denmark
}

\begin{abstract}
A controversial proposal to pilot the training of child protection social workers through an intensive work-based route in England is being supported and funded by the UK Government. Frontline, the brainchild of a former teacher, locates social work training within local authorities ('the agency') rather than university social work departments ('the academy') and has stimulated debate amongst social work academics about their role in shaping the direction of the profession. As a contribution to this debate, this paper explores the duality of social work education, which derives its knowledge from both the academic social sciences and the experience of practice within social work agencies. While social work education has traditionally been delivered by the academy, this paper also explores whether the delivery of training in the allied professions of probation and nursing by 'the agency' is equally effective. Finally, this paper explores the Helsinki model which achieves a synergy of 'academy' and 'agency'. It suggests that there are alternative models of social work education, practice and research which avoid dichotomies between the 'academy' and the 'agency' and enable the profession to be shaped by both social work academics and practitioners.
\end{abstract}

Keywords: social work education; academy; agency; social work research; UK; Finland

Ison-Britannian hallitus on tukenut ja rahoittanut Englannissa kiistanalaista pilottia lastensuojelun sosiaalityöntekijöiden kouluttamiseksi työssä oppimiseen perustuvassa intensiivisessä ohjelmassa. Entisen opettajan ideoimassa Frontline -ohjelmassa sosiaalityön koulutus tapahtuu yhteistyössä paikallisen viranomaistoiminnan yhteydessä eikä yliopiston sosiaalityön laitoksella. Tämä on herättänyt sosiaalityön akateemisten asiantuntijoiden keskuudessa keskustelua heidän roolistaan profession suunnan määrittelyssä. Artikkeli osallistuu tähän keskusteluun tarkastelemalla sosiaalityön koulutuksen kaksijakoisuutta: sen tietoperusta kumpuaa sekä sosiaalitieteistä että sosiaalityön käytännön toimijoiden kokemusperäisestä tiedosta. Sosiaalityön koulutus on perinteisesti annettu yliopistoissa. Artikkelissa tarkastellaan onko rikosseuraamus- ja hoitoalan, jotka ovat samankaltaisia professioita, käytäntöyhteydessä toteutettu opetus yhtä tehokasta. Lopuksi artikkelissa tarkastellaan Helsingin seudulla vakiintunutta toimintamallia, joka saavuttaa tiedeyhteisön ja käytännön synergian. Helsingin toimintamalli esittää vaihtoehtoisen toimintamallin sosiaalityön

*Corresponding author. Email: martin.webber@york.ac.uk 
koulutukseen, käytäntöön ja tutkimukseen. Siinä tiedeyhteisön ja käytännön jako voidaan välttää ja mahdollistaa sekä sosiaalityön akateemisten ja praktisten asiantuntijoiden osallistuminen profession kehittämiseen.

Asiasanat: sosiaalityön koulutus; tiedeyhteisö; käytännön toimija; sosiaalityön tutkimus; Iso Britannia; Suomi

\section{Introduction}

Social work education in Europe operates within diverse historical, political and professional contexts. In the UK, it is highly regulated in contrast to most other European countries (Lymbery, Charles, Christopherson, \& Eadie, 2000). Social work programmes in England, for example, are required to be approved by the Health and Care Professions Council to permit graduates to register as a social worker and to be endorsed by The College of Social Work to achieve benchmark standards for the profession. This limits the latitude of university social work departments in setting their own curricula. Government shaping of social work education through successive reviews [two reviews have commenced in 2013 while the recommendations of the previous one (Social Work Reform Board, 2010) are still being implemented] further prevents social work from becoming a fully autonomous profession and shaping its own destiny in the UK (Welbourne, 2011).

University social work educators in Europe apply knowledge derived from the social sciences and other disciplines in the education and training of social workers and attempt to foster a sense of professional identity within social work students. Social work academics aspire to conduct research of real-world relevance for practitioners and of intrinsic value for its scholarship (Parker \& van Teijlingen, 2012). Its foundation in social theory and social research means that social work practice is inextricably connected to the academy from which it is derived. However, in the UK, where about $80 \%$ of social workers are employed by the state (Moriarty \& Murray, 2007) and social work roles and tasks are largely defined by government policy, there are repeated concerns about social work education not sufficiently preparing students for frontline practice (Clapton, 2013; Social Work Task Force, 2009). This does not appear to occur elsewhere in Europe.

Debate about the readiness to practice of social work students in the UK is not new (Marsh \& Triseliotis, 1996; Pithouse \& Scourfield, 2002). University-based social work programmes are criticised by employers as not adequately preparing students to keep records, write reports, assess risk or manage their time (Marsh \& Triseliotis, 1996; Pithouse \& Scourfield, 2002), for example. This is in contrast to employment-based routes, which came to the fore during crises in the recruitment and retention of social workers (Asquith, Clark, \& Waterhouse, 2005; Cauvain, 2010; Douglas, 2002; Kirkpatrick \& Hoque, 2006; Lymbery, 2004), where newly qualified social workers had acquired many of these skills prior to undertaking the training (Dunworth, 2007; Harris, Manthorpe, \& Hussein, 2008).

A recent proposal generated by the Institute for Public Policy Research think tank to fast-track bright graduates through a focused child protection training programme to become social workers (MacAlister, 2012) has the support of the UK Government but little backing from the social work profession. This is perhaps a sign that leadership of social work education is shifting even further away from the social work academy. It is even possible that entirely non-academic routes into social work may be just around the corner in the UK. Non-governmental organisations (NGOs) provide the majority of social care (non-professionally accredited) training in the UK and it is possible that they may 
also develop social work degree programmes in an increasingly diverse higher education market. Although universities add value to social work education through the practicerelevant research conducted by its academic staff, a lack of research training and the recruitment of university staff primarily as social work educators have reduced the capacity for social work research (Orme \& Powell, 2008). Unless the social work academy can show more effectively how it adds value to social work practice, social work education could be removed from the academy entirely.

The need for the social work academy to be able to communicate to individual students, as well as to social work agencies and political decision-makers, that undertaking a social work degree programme brings added value to professional training is clearly a pressing one. This paper explores this dilemma facing the social work academy.

First, using the example of social work education in the UK and drawing upon interviews with children and family social workers (Cauvain, 2010), we explore the disconnect between students' expectations when they graduate and the reality of social work practice in child protection agencies.

Second, we utilise findings from other practice-based disciplines (nursing and probation) which have shifted between vocational and academic training, to establish what is and is not known about the advantages and disadvantages of professional training within higher education, as a basis for the establishment of priorities for future research into this area of social work.

Finally, we explore the Helsinki model which brings the academy and agency together in Helsinki for their mutual benefit. Although only one example of good practice, it may provide a means to integrate the academy and agency in social work to enrich both.

The focus on the UK and Finland allows greater depth of attention, although it invites extension of the discussion more widely across Europe. At least four factors are at play. First, most programmes in European countries are less highly regulated than the UK, such that aspiring social work students may complete their professional training in a more varied, but perhaps less integrated fashion, such as in Germany, for example. Second, in other parts of Europe the shifts and changes in social work training have been inextricably tied to the practice within social pedagogy. This is the case, for example, in the Baltic states. This also shapes priorities in the research agenda, such that in countries like Denmark research and scholarship in the social work field are referenced against different institutional and policy contexts compared with Finland and the UK. Third, questions of scale and location are important. Some European countries have a very small number of social work programmes, while others have programmes that are located outside the university sector. A final factor at work in social work education flows from the breakup of the Soviet bloc a quarter of a century ago. Several countries can look back to a period prior to the rise of communist governments where social work programmes had begun to emerge, but were then closed or became atrophied and desiccated for half a century. The conclusions we draw from this article need to be read in the context of these limitations.

\section{Social work education in the UK}

The Browne Review (2010) on the sustainability of the university sector in England and Wales led to a substantial increase in student fees of up to $£ 9000$ per year. This led to what some described as a crisis for the academy (Docherty, 2011) as the coalition 
government cut teaching budgets in universities by $80 \%(100 \%$ within the arts, humanities and social sciences). Whilst social work student bursaries are available to some, the largely private funding of undergraduate education (via student loans) has helped to heighten the customer culture in universities, underpinned by the increasing significance of a National Student Survey (NSS) and a 'league table' approach to provision and the student fee regime. While 'rate your professor' sites (e.g. http://www. ratemyprofessors.com) are as yet fairly minimal in Europe we might anticipate their growth in so far as university education becomes increasingly subject to market forces. A third of the students complain of poor value for money courses (Which?/Higher Education Policy Institute, 2013). It is within this context that the role of the social work academy in relation to currency and relevance, effectiveness and preparedness of students for practice, and quality of courses and students, is being scrutinised.

Some UK social work courses have recently closed (King's College London, Southampton, Reading) and, under the coalition government (2010-2015), social work vacancy rates have decreased (Local Government Association, 2013). While this may seem to imply a reduction in need, this seems unlikely with evidence suggesting frontline workers remain overstretched and job satisfaction continues to threaten retention (McFadden, 2012) especially in relation to longer-serving and experienced social workers (Burns \& Christie, 2013).

The art of becoming a professional social worker in the UK involves the 'twin-track approach' of social work education, 'a grounding in a discipline within the social sciences' and of social work training, 'learning how to do it' (Doel, 2012, p. 142). Such an approach, whether complementary or conflictual, distinctly aligns education with the academy and training with the agency. This road to professional status is justifiably one of both challenge and reward, reflecting the reality and complexity of practice. Students must successfully complete 170 days of assessed work-based learning, usually across two placements, and attain passes in a variety of academic modules across the course (General Social Care Council, 2012). The twin-track approach, therefore, serves to prepare students for professional employment within the diverse range of social work settings.

The currency and relevance of social work courses are particularly upheld by the academic team delivering the 'grounding' and practice educators providing the 'training'. 'Grounding' in social work reflects theories, values and the complexities of human beings working with each other, often in times of great need. Social work research necessarily feeds and nourishes the wide-ranging knowledge base which students use overtly or tacitly, consciously or unconsciously, within their placements. The connectedness of these elements also needs to be taught, experienced and understood by all involved in the education of social workers.

Criticism has been levelled at courses where the need to apply theory to practice is not always reflected in the practice experience, where the need to 'hit the ground running' prevails. A typical response (from an empirical study of social work with children and families) was: 'I don't particularly feel that the universities are equipping social workers with the right skills to come and join local authority children and families teams' (children and families social worker, Cauvain, 2010). Likewise, critical analysis of peerreviewed journal articles can feel somewhat incongruous with daily social work.

The previous social work education regulator in England identified prolonged concerns over the supply, quality and relevance of practice placements for social work students (General Social Care Council, 2012). Experienced practitioners also expressed disbelief at poor standards of basic writing skills, including grammar and the lack of 
Table 1. Mismatch between social work student expectations and realities (Cauvain, 2010).

\begin{tabular}{ll}
\hline Student expectation & \multicolumn{1}{c}{ Perceived reality } \\
\hline Direct work-helping people & Commissioning \\
Making a difference & Meeting a target \\
Time to 'do the job' & Time limitations and Integrated Children's \\
& System (ICS) \\
Relationship-based approach & Crisis management \\
Culture of reflection and evaluating progress & Culture of audit \\
Preventative work & Child protection work \\
Available resources & Service and budget cuts \\
\hline
\end{tabular}

experience of some students. For example: 'I think resilience is possibly in the process of being eroded; accepting students onto the social work degree with little or no real life experience and social work practice in non-statutory sectors' (senior children and families social worker, Cauvain, 2010). Universities report an increasing number of assessments of students with learning difficulties, including dyslexia, that affect ability in reading and writing (Tinklin, Riddell, \& Wilson, 2001; Vickerman \& Blundell, 2010). Students also share concerns, highlighting a disconnect between their expectation and the perceived reality of practice (Cauvain, 2010), as shown in Table 1.

Evidence suggests links between the negativity around these experiences, feelings of detachment towards the employer, increased likelihood of retention problems and subsequent burden on the remaining colleagues (Figure 1).

A key element of UK social work education appears to be the need for both the academy and the agency to effectively manage student expectations. In doing so, academics must consider the academy's influence in student disconnect and whether their

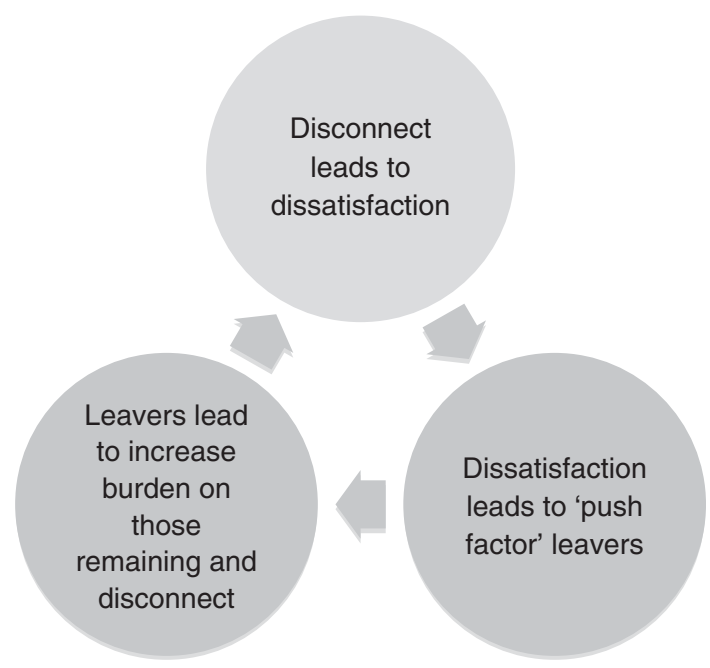

Figure 1. Cycle of disconnect and dissatisfaction. 
contribution is relevant, contemporary and of high quality. Fundamentally, we should teach in the light of the implications that the perceived reality of practice has for social work. It is also important to reflect on the connectedness of the academy and agency to each other and to their students, and the connections of individual academics to social work practice. Discourse around expectations is essential and should involve a process of asking questions, actively listening to responses, clarifying issues and acting upon them.

As previously acknowledged, the complexities involved in working with human beings can be both challenging and rewarding; committed and connected students are likely to become committed, connected and retained social workers. Positive dialogue between the academy, agency and students based on reciprocity and a united aim for social justice can lead to successful social work education. This implies a fundamental need for duality; for course content that maintains currency and relevance; an ability to effectively prepare students for practice; and be of a quality that yields high-calibre social workers who will serve their service users well.

\section{The effectiveness of higher education in the training of nursing and probation professionals}

Arguably, then, the quality of social work practice is better as a result of training which incorporates significant input from academics within institutions of higher education alongside and as part of preparation for practice. But what evidence supports this proposition? In fact, there is a paucity of research that enables us either to confirm or refute the presumed advantages of higher education as the preferred location for social work training. Orme (2012) suggests that both 'snapshot' and 'moving picture' evaluations have in built limitations, and so neither is well placed to address the issue of impact on practice outcomes. As Burgess and Carpenter (2010) conclude, their own work "provided only limited evidence of outcomes in terms of changes in behaviour ... and no evidence of the impact of social work education on the lives of service users and carers' (2010, p. 129). Consequently, the social work academy is not well placed to demonstrate whether or not the quality of outcomes in professional social work is better under work- or university-based routes to qualification.

One way in which we might enhance our understanding in this area is via comparative review of how such shifts have impacted in other practice-based disciplines. Concerns about the quality of professional training and practice are not limited to social work (Moriarty, Manthorpe, Stevens, \& Hussein, 2011). In some disciplines, there have been recent shifts which might enable us to establish some parameters for this discussion. Nursing and probation are both similar to, and, in the UK at least, have links with, social work. Nursing is generally regarded as a 'caring' profession, which emphasises reflective practice, critical reflection and critical appraisal as sense-making activities. Over the last two decades, it has shifted in the UK from a vocational pathway to an academic one. Probation officers, meanwhile, trained as or alongside social workers until 1997, but are now trained wholly 'on the job' with very little input from academics. The findings of research into the impact of these shifts on the quality of practice and outcomes may enable us to establish the advantages and disadvantages of professional training within higher education, and inform debates about the future of social work education.

The introduction of university-delivered pre-registration nursing education stemmed from reforms initiated in the mid-1980s, which culminated in the requirement that a 
bachelor's degree would be the minimum academic level for all nurses across the UK as of 2013. This was intended to ensure 'fitness to practice' at point of registration (Willis, 2012). Process-oriented studies have investigated the consequences of these changes. For example, Lauder et al. (2008) found consensus amongst key stakeholders that nurses trained with university involvement were 'fit for practice' at point of registration, which represented a major change from earlier studies. There have also been studies focusing on the development of key skills (e.g. Thompson \& Stapley, 2011). Although these findings point to advantages arising from the involvement of higher education in professional training, there has been no large-scale evaluation of whether or not the shift 'from the vocational to the academic' has led to higher quality nursing practice or improved outcomes to further substantiate them.

In probation, there has been a substantial amount of research undertaken into the changing nature and quality of practice since the 'messy divorce' (McNeill, Bracken, \& Clarke, 2010) from social work. Initially, this focused on large-scale evaluation of effectiveness, under the banner of 'what works' or 'the effective practice initiative'. These initiatives were curtailed-controversially-before the results were in, on the basis of political rather than empirical considerations (Maguire, 2004; Raynor, 2004). Again, it is apparent that there has been no attempt to evaluate whether or not, or in what ways, the change of training route has impacted on the actual outcomes of practice. Possibly, this is because there was no prospect that probation training would return to the social work fold. Instead, official audit 'focused largely on issues of compliance with the regulatory framework and no evaluation was undertaken of the overall impact of the diploma on service delivery' (Knight \& Ward, 2012, p. 160). Subsequently, much research has been small scale, practitioner focused and concerned with the nature and quality of practice under 'the new regime', comparing 'old' and 'new' school approaches to probation (Annison, Eadie, \& Knight, 2008; Fitzgibbon, 2011; Gregory, 2010). Generally, these conclude that contemporary arrangements represent 'a more instrumental and functional training programme based on expediency and pragmatism' (Knight \& Ward, 2012, p. 179) and query whether the new route enables staff to 'make complex judgements in unpredictable and uncertain circumstances ... to think, analyse and reflect, confident in the depth of knowledge and understanding that they can bring to their practice' (Knight \& Ward, 2012, p. 174).

The impetus for change in nursing and probation was arguably similar-both stemmed from concerns about the quality of practice and threats to professional legitimacy_but the approaches that the different professions took were diametrically opposed. In the case of nursing, one of the presumed advantages of higher educationbased professional education was the privileged status of academic knowledge, which is possibly seen as more robust than more vocationally derived understanding, thus strengthening the legitimacy of the profession. And yet, responses to recent health care failings routinely include a critique of the privileged role accorded to academic knowledge by nurses trained under the new arrangements (e.g. Francis, 2010). Indeed, some practitioners are amongst those who denounce the emphasis on 'scientific' knowledge at the expense of 'good old fashioned' nursing care. High-level requirements of university-based training 'exclude potential nurses who are kind hearted rather than clever' (Willis, 2012, p. 29) and patients and nursing are vulnerable as a result. In probation, meanwhile, after a period in which service failures attracted equally critical attention (see Fitzgibbon 2011 for a review), managerial constraints on professional 
discretion have been significantly lessened with the introduction of new national standards which emphasise the role of professional judgement in decision-making.

In the absence of empirical evaluation, it does appear that shifts in the nature and context of professional training do not necessarily appear to have had the effects that were anticipated. A higher education base for nurse training was intended to ensure that health care 'failures' be reduced, and that where they did occur, practitioners and profession were protected against the charge that nursing was not rigorous in its approach to health care standards. Recent reaction to health care scandals (Department of Health, 2013) suggests this defence is by no means watertight. The absence of any large-scale evaluation of the impact that the shift to higher education has had on the outcomes of nursing practice makes this defence (if warranted) more difficult to sustain than need be the case. At the same time, the last few years have witnessed a resurgence of interest in relationship-based approaches to probation practice. Interestingly, some advocates of evidence-based practice in US social work have moved to make the same plea. Munson (2004, p. 259), for example, pleads for a version of evidence-based practice that is 'balanced with a relationship model'. He argues that intervention 'must have a developmental focus using a scientific perspective that relies on evidence that is grounded in a therapeutic relationship' (p. 252). Evidence alone and relationship alone do not produce change, but both-and practice that is thus based-have ethical implications. While advocates of a 'strong' version of evidence-based practice appear to believe that the main risks of being unethical lie in being non-rational, Munson suggests that '[there] must be monitoring for the subtle belief that only evidence-based tasks or outcomes have value' (p. 254). Evidence-based practice must, he believes, address power issues and ethical aspects of, for example, lack of expressive capacity in traumatised children. The irony is that at the time when skills taught on social work programmes became 'officially' relevant to probation work (Rex, 2010), the last vestiges of higher education involvement in probation training are finally disappearing.

\section{The Metropolitan Praksis: Enhancing transformative practice by the means of social work practice courses and learning network}

Whether social work education is located in the academy or the agency, university social work can maintain its vitality by developing models which span the realms of practice and research. The Helsinki model of organising the interaction between academy and agency is an example of a solution to the question of the role of university social work in relation to practice. The model has become known as a creative solution for facilitating a dialogue between the different cultures and tasks of social work practice, education and research, and, if translated to a UK context, may help university social work departments meaningfully articulate their role in relation to the social work agencies they work with.

In Finland, a considerable gap in the relations of practice, education and research evolved since the late 1970 s as a consequence of academised social work education as part of social science studies. At the time social work did not exist as an independent academic discipline but was loosely considered to be some kind of micro-social policy. At first, the burden of applying research methods, theoretical concepts and ideas in practice was left to practitioners. It was soon discovered that this did not work; academically trained social workers were not able to act as pioneers alone in building the bridge between theory and practice. 
Both the University and City of Helsinki agreed that more research skills were necessary in order to create a mutually enriching solution for developing a reflective social work discipline and future-oriented practitioners, as well as renewing social services. All these ideas were to some extent combined when the Heikki Waris Institute was established in 2000. The new institute provided a new mediating structure between research, teaching and social work practices (which the university sought) and new knowledge and innovative interventions in urban social issues and skilful practitioners who were able to develop the service provided by the City of Helsinki (Kananoja, 2009). Elementary parts of the new concept included two closely connected functions which were soon termed Praksis and Practice Research (Karvinen-Niinikoski, 2005; Satka, Karvinen-Niinikoski, Nylund, \& Hoikkala, 2005).

Praksis consists of four courses during BA and MA studies in social work (58 ETC credits). The overall aim is to create a learning network based on the idea of transformative, reflective learning of all contributors. The main platform is a learning network of social work agencies in child welfare services and social work with adults in addition to NGOs and governmental agencies. The first three courses are: (1) getting acquainted with helping in NGOs, (2) basic skills of psychosocial social work and (3) advanced social work skills in public sector settings. The last (4) is practice research in various settings including a Metropolitan Practice Research Forum, a yearly event for agencies and the university to reflect on outcomes and discuss aims for the future. The courses are organised together with the university lecturers and the agencies with the mediation of the Institute.

Praksis helps various participants to bridge the gap between education and training (see Table 2) via trialogical learning (Paavola, Engeström, \& Hakkarainen, 2012), which is collaborative knowledge creation with knowledge artefacts for transformations in

Table 2. The benefits of the collaborative Praksis model in social work education.

\begin{tabular}{lll}
\hline & \multicolumn{1}{c}{ Presently } & \multicolumn{1}{c}{ In the future } \\
\hline Students & $\begin{array}{l}\text { Becoming reflective social workers } \\
\text { able to use various types of } \\
\text { knowledge; learning to } \\
\text { systematically create new knowledge } \\
\text { and practice research }\end{array}$ & $\begin{array}{l}\text { Able to coproduce knowledge with } \\
\text { service users and professionals; } \\
\text { development of a research-minded } \\
\text { social work profession }\end{array}$ \\
$\begin{array}{c}\text { Social work } \\
\text { teams and } \\
\text { practice } \\
\text { teachers }\end{array}$ & $\begin{array}{l}\text { with the students and practice } \\
\text { teachers }\end{array}$ & $\begin{array}{l}\text { New understanding, for example about } \\
\text { transforming objects of social work } \\
\text { with themselves as actors }\end{array}$ \\
$\begin{array}{c}\text { Sexperts by } \\
\text { experience }\end{array}$ & $\begin{array}{l}\text { Getting support for themselves; able } \\
\text { to help service development; learning } \\
\text { to coproduce }\end{array}$ & $\begin{array}{l}\text { Feeling empowered and skilled in } \\
\text { activities of coproduction }\end{array}$ \\
$\begin{array}{c}\text { University } \\
\text { teachers }\end{array}$ & $\begin{array}{l}\text { Gaining up-to-date information for } \\
\text { practice; relevant knowledge } \\
\text { production and teaching }\end{array}$ & $\begin{array}{l}\text { Active agents in collaborative } \\
\text { knowledge production; agents for } \\
\text { change }\end{array}$ \\
$\begin{array}{c}\text { Managers, } \\
\text { leaders and } \\
\text { politicians }\end{array}$ & $\begin{array}{l}\text { Supplied by up-to-date information } \\
\text { about services, people's concerns and } \\
\text { needs }\end{array}$ & $\begin{array}{l}\text { Participants in co-productive dialogues; } \\
\text { knowledgeable decision-makers }\end{array}$ \\
\hline
\end{tabular}


practice. The concept refers to the practice turn in social science (Schatzki, Knorr Cetina, \& von Savigny, 2001) and builds on classic approaches emphasising mediation as a basis for human activities. It emphasises knowledge artefacts as things which mediate activities but are also taken themselves as objects to be created and developed by the actors.

Practicing social workers participate in co-production processes to transform both education and practice. Consequently, these processes also enhance continuous learning in organisations, and the outcomes are both material—research reports, teaching materials and academic articles_-and immaterial—breathing, dynamic and innovative actors and organisations.

Praksis is a socially mediated learning network. The epistemic tools include, for example, learning assignments which apply tools of research and reflection, are developed in co-production processes, and are the platform of learning for students, practitioners and university teachers.

This model does not consider academia and practice as separate entities (see Marthinsen, Julkunen, Uggerhöj, Rasmussen, \& Karvinen-Niinikoski, 2012). Participants work together in a net connecting teachers and students with work-teams and practice teachers in the field, and also with the managers, service users and experts by experience in the surrounding community, including NGOs. They are starting to see minor systemic changes ahead. One of them is that social work graduates are valued by both the service users and employees because of their attitude towards knowledge production and research in practice. On the other hand, academics have been able to follow the timely changes in urban social work practice, both on the level of the collaborating work-teams and on the collaborating service users. Furthermore, research with experts by experience produces new collaborative methods and improved services for people. This positions academics side-by-side with social workers to take a stronger role in the local politics as advocates and collaborative voices in making decisions for the future of social work.

The Finish model often raises questions about the evidence of its outcomes. While no formal evaluations have been conducted, the model has been adopted as the promising point of departure to reorganise the curriculum in other Finnish universities. A report for the Ministry of Social Affairs and Health Education (Sosiaalialan korkeakoulutuksen suunta, 2007) recommended the use of the model when it suggested a partly state-funded national model for social work education in a 'study and research municipality' based on the productive interaction and experience by practitioners, academics and students in the Helsinki region. Therefore, it has become a source of learning and rethinking for all partners and most of the Finnish universities (e.g. Saurama \& Julkunen, 2012).

\section{Conclusion}

There is no clear evidence that professional education is best located in the academy or the agency. Existing evaluation of outcomes in social work education largely focuses on process and quality rather than effectiveness (Carpenter, 2011). However, there is evidence to suggest that conceptual linkage activities are more strongly related to learning outcomes than observational or participatory activities in social work practice placements (Lee \& Fortune, 2013), suggesting an integration of theory into practice supports learning more effectively than just 'doing the job'. Similarly, an examination of students' reflective practice logs found a high level of integration of knowledge and skills in social work practice placements (Lam, Wong, \& Leung, 2007). 
Limited evidence suggests that existing models of practice education (located in the academy with placements within agencies) effectively allow students to integrate knowledge and practice. However, there are considerable methodological difficulties entailed in identifying and capturing the links between training programmes and subsequent practice quality. This may be a complex question, but given the threats social work faces, it is one with which it needs to engage. One way forward stems from the potential that 'realism' offers as a means of answering questions about the nature of working with complexity (Geyer \& Rihani, 2010; Hudson, 2010; Pawson, 2013). Given the evident complexity of this task, might there also be potential to approach the evaluation of the outcomes of social work education on practice from a realist perspective? After all, there have been meaningful and useful realist evaluations of social work (e.g. Kazi, 2003), so why not social work education?

It may well enable us to think about how we might meaningfully evaluate the outcomes of social work, and of social work education, in ways which are different to the approaches encapsulated in snapshot or moving pictures approaches. There are now various approaches to capturing complexity that interested researchers might draw upon to operationalise the causal connections between the setting for social work training and outcomes of social work processes and interventions, from the perspectives of a variety of stakeholders. This means actively supplementing the assessment of disaggregated components of quality and effectiveness with a wholesale push to establish the respective strengths and limitations of academic and vocational routes in terms of actual outcomes in practice. This will be a challenging endeavour. But whatever the results, social work will be stronger if the benefits of the various routes to qualification are substantiated rather than merely claimed.

In retrospect, it is arguably unhelpful to think about social work as a separation between the academy and agency. Many social work academics continue in frontline practice or maintain close connections with practice through their research or other independent work. Many practitioners contribute to social work programmes as practice educators or visiting lecturers. We should not assume that there is a significant gap between agency and the academy or that the relationship is uniform across Europe or within European countries. However, where a gap exists, university social work can usefully position itself closer to practice to enhance the collaborative potential of academics, practitioners and service users to work together for the mutual and collaborative development of the profession. The Metropolitan Praksis model in Helsinki provides one example of how this can be achieved and illustrates the benefits of closer integration for the profession and, ultimately, the vulnerable people it seeks to serve.

\section{Notes on contributors}

Martin Webber is Anniversary Reader in Social Work and Director of the International Centre for Mental Health Social Research in the Department of Social Policy and Social Work at the University of York. His primary research interests are in the development and evaluation of social interventions with people with mental health problems. He is a registered social worker and, through his role as Academic Lead for Making Research Count at York, supports the integration of research findings into social work practice.

Mark Hardy is Lecturer in Social Work in the Department of Social Policy and Social Work at the University of York. He is co-author (with Tony Evans) of Evidence and Knowledge for Practice (Polity) and is currently completing a monograph-Governing risk? Care and control in contemporary social work - for Palgrave Macmillan. 
Simon Cauvain is Lecturer in Social Work in the Department of Social Policy and Social Work at the University of York. His primary research interests are in the frontline experiences of social work that impact on recruitment and retention, especially within services for children and families. He is also a registered social worker and member of the British Association of Social Workers.

Aino Kääriäinen is University Lecturer at the Department of Social Research at the University of Helsinki. She also works at Heikki Waris Institute, being one of the resource persons for social work practice learning and research in the Helsinki Metropolitan Area. Her research interests include documentation in child protection social work, family care and parenthood after divorce. She also acts as expert member at Helsinki Administrative Court in children's care issues.

Mirja Satka is Professor in Social Work Practice Research at the Department of Social Research at the University of Helsinki. As part of her post she supervises the pedagogical activities and practice research projects at Heikki Waris Institute, and acts as an expert in social work practice research in the Helsinki Metropolitan Area. Her research interests also include university pedagogy, childhood research and the history of social work.

Laura Yliruka is Senior Researcher Social Worker and the Head of Heikki Waris Institute which belongs to the Centre of Expertise on Social Welfare in Helsinki Metropolitan Area, Socca. Her research interests include social work expertise, epistemic knowledge practices and innovations as well as working conditions of social work.

Ian Shaw is Professor of Social Work in the Department of Social Policy and Social Work at the University of York, and Professor in the Department of Sociology and Social Work at Aalborg University. His current research includes archival work on the genealogy of social work in relation to sociology, and a forthcoming work on Social work and science.

\section{References}

Annison, J., Eadie, T., \& Knight, C. (2008). People first: Probation officer perspectives on probation work. Probation Journal, 55, 259-271. doi:10.1177/0264550508095122

Asquith, S., Clark, C., \& Waterhouse, L. (2005). The role of the social worker in the 21st centuryA literature review. Edinburgh: Scottish Executive.

Browne, J. (2010). Securing a sustainable future for higher education: An independent review of higher education and student finance. Retrieved May 14, 2013, from https://www.gov.uk/ government/uploads/system/uploads/attachment_data/file/31999/10-1208-securing-sustainablehigher-education-browne-report.pdf

Burgess, H., \& Carpenter, J. (2010). The outcomes of social work education: Developing evaluation methods. Southampton: Higher Education Academy/SWAP.

Burns, K., \& Christie, A. (2013). Employment mobility or turnover? An analysis of child welfare and protection. Children and Youth Services Review, 35, 340-346. doi:10.1016/j.childyouth. 2012.11.014

Carpenter, J. (2011). Evaluating social work education: A review of outcomes, measures, research designs and practicalities. Social Work Education: The International Journal, 30, 122-140. doi:10.1080/02615479.2011.540375

Cauvain, S. (2010). Recruitment and retention of children and family social workers: A case study (PhD thesis). Sheffield Hallam University, Sheffield.

Clapton, G. (2013). Minding the gap: Assisting the transition from the academy to the profession. Social Work Education, 32, 411-415. doi:10.1080/02615479.2012.657173

Department of Health. (2013). Patients first and foremost. The initial government response to the report of the Mid Staffordshire NHS Foundation Trust Public Inquiry. London: The Stationery Office.

Docherty, T. (2011). For the university. London: Bloomsbury.

Doel, M. (2012). Social work: The basics. London: Routledge.

Douglas, A. (2002). Is anybody out there? Recruitment and retention in social care in London. Community Care, 1427, 38-40. 
Dunworth, M. (2007). Growing your own: The practice outcomes of employment-based social work training. An evaluative case study of one agency's experience. Social Work Education: The International Journal, 26, 151-168. doi:10.1080/02615470601042664

Fitzgibbon, W. (2011). Probation and social work on trial: Violent offenders and child abusers. Basingstoke: Palgrave Macmillan.

Francis, R. (2010). Independent inquiry into care provided by Mid Staffordshire NHS Foundation Trust January 2005 - March 2009. London: The Stationery Office.

General Social Care Council. (2012). Regulating social work education (2001-12). Learning Report. London: General Social Care Council.

Geyer, R., \& Rihani, S. (2010). Complexity and public policy: A new approach to 21st century politics, policy and society. London: Routledge.

Gregory, M. (2010). Reflection and resistance: Probation practice and the ethic of care. British Journal of Social Work, 40, 2274-2290. doi:10.1093/bjsw/bcq028

Harris, J., Manthorpe, J., \& Hussein, S. (2008). What works in 'Grow your own' initiatives for social work? Research report. London: General Social Care Council.

Hudson, C. G. (2010). Complex systems and human behaviour. Chicago, IL: Lyceum.

Kananoja, A. (2009). Practice-research in social work in Finland. Unpublished report. Retrieved June 26, 2013, from http://www.socca.fi/files/1050/Practice_research_paper_kananoja_June2009.pdf

Karvinen-Niinikoski, S. (2005). Research orientation and expertise in social work: Challenges for social work education. European Journal of Social Work, 8, 259-271. doi:10.1080/13691 450500210756

Kazi, M. A. F. (2003). Realist evaluation in practice: Health and social work. London: Sage.

Kirkpatrick, I., \& Hoque, K. (2006). A retreat from permanent employment?: Accounting for the rise of professional agency work in UK public services. Work, Employment and Society, 20, 649666. doi:10.1177/0950017006069806

Knight, C., \& Ward, D. (2012). Probation education and training: An overview of the research. In J. Lishman (Ed.), Social work education and training (pp. 154-183). London: Jessica Kingsley.

Lam, C. M., Wong, H., \& Leung, T. T. F. (2007). An unfinished reflexive journey: Social work students' reflection on their placement experiences. British Journal of Social Work, 37, 91-105. doi:10.1093/bjsw/bcl320

Lauder, W., Roxburgh, M., Holland, K., Johnson, M., Watson, R., Porter, M., ... Behr, A. (2008). Nursing and midwifery in Scotland: Being fit for practice. The report of the evaluation of fitness for practice pre-registration nursing and curricula project. Dundee: NHS Education for Scotland.

Lee, M. G., \& Fortune, A. E. (2013). Patterns of field learning activities and their relation to learning outcome. Journal of Social Work Education, 49, 420-438.

Local Government Association. (2013). Local government workforce survey 2011/12: Summary findings for England. London: Author.

Lymbery, M. (2004). Responding to crisis: The changing nature of welfare organisations. In M. Lymbery \& S. Butler (Eds.), Social work ideals and practice realities (pp. 34-56). Basingstoke: Palgrave Macmillan.

Lymbery, M., Charles, M., Christopherson, J., \& Eadie, T. (2000). The control of British social work education: European comparisons. European Journal of Social Work, 3, 269-282. doi: $10.1080 / 714052830$

MacAlister, J. (2012). Frontline. Improving the children's social work profession. London: Institute for Public Policy Research.

Maguire, M. (2004). The crime reduction programme: Reflections on the vision and the reality. Criminal Justice, 4, 213-238.

Marsh, P., \& Triseliotis, J. (1996). Ready to practise? Social workers and probation officers: Their training and first year in work. Aldershot: Ashgate.

Marthinsen, E., Julkunen, I., Uggerhöj, L., Rasmussen, T., \& Karvinen-Niinikoski, S. (Eds.). (2012). Practice research in Nordic social work. Knowledge production in transition. London: Whiting \& Birch.

McFadden, P. (2012). Resilience and burnout in child protection social work in Northern Ireland. Belfast: University of Ulster.

McNeill, F., Bracken, D., \& Clarke, A. (2010). Social work in criminal justice. In I. Shaw, K. BriarLawson, J. Orme, \& R. Ruckdeschel (Eds.), The Sage handbook of social work research (pp. 447-462). London: Sage. 
Moriarty, J., \& Murray, J. (2007). Who wants to be a social worker? Using routine published data to identify trends in the numbers of people applying for and completing social work programmes in England. British Journal of Social Work, 37, 715-733. doi:10.1093/bjsw/bch325

Moriarty, J., Manthorpe, J., Stevens, M., \& Hussein, S. (2011). Making the transition: Comparing research on newly qualified social workers with other professions. British Journal of Social Work, 41, 1340-1356. doi:10.1093/bjsw/bcr031

Munson, C. E. (2004). Evidence-based treatment for traumatized and abused children. In A. R. Roberts \& K. R. Yeager (Eds.), Evidence-based practice manual: Research and outcome measures in health and human services. New York, NY: Oxford University Press.

Orme, J. (2012). Evaluation of social work education. In J. Lishman (Ed.), Social work education and training (pp. 15-34). London: Jessica Kingsley.

Orme, J., \& Powell, J. (2008). Building research capacity in social work: Process and issues. British Journal of Social Work, 38, 988-1008. doi:10.1093/bjsw/bcm122

Paavola, S., Engeström, R., \& Hakkarainen, K. (2012). The trialogical approach as a new form of mediation. In A. Moen, I. Morch, \& S. Paavola (Eds.), Collaborative knowledge creation (pp. 114). Rotterdam: Sense.

Parker, J., \& van Teijlingen, E. (2012). The research excellence framework (REF): Assessing the impact of social work research on society. Practice, 24, 41-52. doi:10.1080/09503153.2011. 647682

Pawson, R. (2013). The science of evaluation: A realist manifesto. London: Sage.

Pithouse, A., \& Scourfield, J. (2002). Ready for practice? The DipSW in Wales: Views from the workplace on social work training. Journal of Social Work, 2, 7-27. doi:10.1177/146801 730200200102

Raynor, P. (2004). The probation service 'Pathfinders': Finding the path and losing the way? Criminal Justice, 4, 309-324.

Rex, S. (2010). Offender engagement programme. East of England: National Offender Management Service.

Satka, M., Karvinen-Niinikoski, S., Nylund, M., \& Hoikkala, S. (Eds.). (2005). Sosiaalityön käytäntötutkimus [Practice research in social work]. Helsinki: Palmenia.

Saurama, E., \& Julkunen, I. (2012). Approaching practice research in theory and practice. In E. Marthinsen, I. Julkunen, L. Uggerhöj, T. Rasmussen, \& S. Karvinen-Niinikoski (Eds.), Practice research in Nordic social work. Knowledge production in transition (pp. 171-191). London: Whiting \& Birch.

Schatzki, T. R., Knorr Cetina, K., \& von Savigny, E. (Eds.). (2001). The practice turn in contemporary theory. New York, NY: Routledge.

Social Work Reform Board. (2010). Building a safe and confident future: One year on. Detailed proposals from the social work reform board. London: Department for Education.

Social Work Task Force. (2009). Building a safe, confident future. The Final Report of the Social Work Task Force. London: Department for Children Schools and Families.

Sosiaalialan korkeakoulutuksen suunta. (2007). Työryhmämuistioita 43 [Direction for higher education in social work and social welfare]. Helsinki: Ministry of Education.

Thompson, C., \& Stapley, S. (2011). Do educational interventions improve nurses' clinical decision making and judgement? A systematic review. International Journal of Nursing Studies, 48, 881893. doi:10.1016/j.ijnurstu.2010.12.005

Tinklin, T., Riddell, S., \& Wilson, A. (2001). Wider access for disabled students? Paper presented at the Society for Research into Higher Education Conference, Cambridge University.

Vickerman, P., \& Blundell, M. (2010). Hearing the voices of disabled students in higher education. Disability and Society, 25, 21-32. doi:10.1080/09687590903363290

Welbourne, P. (2011). Twenty-first century social work: The influence of political context on public service provision in social work education and service delivery. European Journal of Social Work, 14, 403-420. doi:10.1080/13691451003706670

Which?/Higher Education Policy Institute. (2013). The student academic experience survey. Retrieved June 24, 2013, from http://www.hepi.ac.uk/455-2154/2013-Student-Academic-Experi ence-Survey-produced-jointly-by-HEPI-and-Which.html

Willis, P. (2012). Quality with compassion: The future of nursing education. Report of the Willis Commission. London: Royal College of Nursing. 